\title{
CREATING A BRAND OF THE INTELLIGENT ENTERPRISE THROUGH BUILDING RELATIONSHIPS WITH STAKEHOLDERS
}

\begin{abstract}
The purpose of this article is to present the creation of the brand in the intelligent organization mostly based on the building relationships with stakeholders. In contemporary organizations, a lot of attention is paid to different levels of organizational intelligence which is supported by creativeness and innovations of varied groups of interests. Internal and external stakeholders increasingly indicate directly what has the greatest impact on their satisfaction or dissatisfaction within the cooperation with the enterprise. Many international studies prove that the strong brand increases numbers of advantages for the organization such as: raising trust among stakeholders towards the products and the organizational culture of the enterprise, giving the chance to build customer loyalty, psychologically evaluating the image of the organization, enabling the company positioning on the market perception map and in the cyberspace, stabilizing the market position of the enterprise and others. Stakeholders, in majority, expect more initiatives from the enterprise due to the engagement process and the organization can achieve many goals by fulfilling partners` needs and by the creation of the strong brand on the market. Therefore, it can be assumed that building permanent relationships with stakeholders and strengthening their involvement in the contemporary world of business is of permanent importance in creating the brand and image of each organization. The author tries to define the features of the intelligent organization brand and list various aspects of "intelligence" in the company, based on the subject literature and own research, on the example of a case study presenting the activities of Apple Company.
\end{abstract}

Keywords: brand`s creation, intelligent enterprise, relationships with stakeholders, Apple company. "A strong brand should have a rich, clear brand identity - a set
of associations the brands strategist seeks to create or main-
tain. A brand identity is aspirational and may imply that the
image needs to be changed or augmented"

D.A. Aaker

\footnotetext{
${ }^{1}$ Wioletta Wereda, PhD, Faculty of Cybernetics, Institute of Organization and Management, Military University of Technology in Warsaw, ul. Gen. Witolda Urbanowicza 2, 00-908 Warszawa 46; e-mail: weredawioletta@tlen.pl. ORCID: 0000-0002-6948-0239.

Dr Wioletta Wereda, Wydział Cybernetyki, Instytut Organizacji i Zarządzania, Wojskowa Akademia Techniczna, ul. Gen. Witolda Urbanowicza 2, 00-908 Warszawa 46; e-mail: weredawioletta@tlen.pl. ORCID: 0000-0002-6948-0239.
} 


\section{INTRODUCTION}

In the conditions of a variable, competitive, technologically rapidly growing and marketing market, having a strong brand by a company allows achieving and maintaining a competitive advantage. A strong brand with high capital distinguishes the brand's loyalty, awareness and positive associations associated with the brand, as well as its high perceived quality. Nowadays, companies are building their value on reputation and building an organizational identity based on the aspect of intelligence, the business and rapid development ${ }^{2}$.

The importance of the brand in the development of marketing activities is undisputable. Creating the brand enables market segmentation and allows adapting to the changing market needs. The benefit of the brand's existence is, inter alia, the protection of the product against imitators, its innovativeness and uniqueness. The more the brand is present in consumer awareness, it has the reputation of a high quality brand, creates loyalty of buyers, uses positive associations with its name and symbolism and protects against imitation, the more effectively it enables the company to achieve market success. In the new approach to brand marketing, we are moving away from selling products for the sake of selling dreams, because together with a recognizable brand, we acquire the feeling of: reliability, uniqueness and exclusivity. Branding is a communication strategy, a password, an identity of the image and a logo. An important role is also played by the capital of the brand, which strengthens the value of the brand, creates positive associations with customers. It is an intangible asset that indicates its importance, which results from the perception of quality and customer associations related with a given product. Investing in the capital of the brand allows us to assess the competitive possibilities of the brand ${ }^{3}$.

The main goal of the article is to show the importance of the brand as a resource of intangible, permanent value in the functioning of a modern, intelligent enterprise, especially through building effective relationships with the organization's closest stakeholders. The more specified aims of the paper are threefold. Firstly, to identify the creation of the brand of the intelligent enterprise; secondly to determine the role of closest stakeholders in developing the brand on the market, and thirdly to present the case study, an example of the company that is trying to reach such a situation in the global contemporary business, namely Apple company.

\section{THEORETICAL BACKGROUND}

\subsection{State of art in creating a brand of the organization}

In the era of ubiquitous Internet, progressive globalization and the information society, enterprises have faced the task of (and what's important, they are re-creating each day) modifications, flexible matching and current creation of their offer in line with the main market determinants. Marketing and its tools have become the means to cope with the ongoing changes.

\footnotetext{
${ }^{2}$ L. Bivainiene, Brand Image Conceptualization: The Role of Marketing Communication, "Economics and Management" 2007, Vol. 12, No. 2, p. 22.

${ }^{3}$ E. Skrzypek, F. Pinzaru, Marka jako ważny element marketingu, Zeszyty Naukowe Uniwersytetu Przyrodniczo-Humanistycznego w Siedlcach, Seria: Administracja i Zarządzanie, No. 141/2017, p. 198-199.
} 
It is the brand that is the leader among the tools of competing on the market, which proves the company's position. Brands draw companies; they rank them mechanically at various levels of the market. The condition of the company is directly proportional to the condition of the brands it wields, so by caring for the brand, it takes care of the success of business. Its status affects the product, price, shape of promotion or distribution channels. This means that as the brand's strength, level of recognition and the number of positive associations that it evokes increases; the position of the company in the eyes of intermediaries also increases. Taking care of perceived quality of products, it is possible to daringly apply the policy of high prices and makes the form of promotion dependent on this. In turn, properly selected distribution methods narrow down and specify the places of sale of these goods 4 .

The brand concept consists of aggregated categories, i.e. a "trade brand", or a product brand which, as its name says, is closely related to the product and the "brand of the company". Undoubtedly, both models of the brand's image overlap with each other. One can testify to the situation and performance of the other. However, it is not always possible to meet in the literature the difference between the term brand and more detailed descriptions. However, in the eyes of consumers brands have different categories and according to D. Aaker eight categories can be distinguished ${ }^{5}$ :

1. Master brand - the main identifier of the company's offer is a reference point for consumers; the leading feature of the main brand is its eye presence in the foreground (product packaging);

2. Endorser brand - usually the brand of a corporation that ensures the credibility of a given offer, adding its positive associations, acts as a reducer of purchasing risk (i.e. Nestlé);

3. Subbrand - makes it more attractive or changes the associations created by the main brand in a specific product context; the purpose of the sub-brand is to differentiate the offer from the main brand by adding a new attribute or a separate personality element, which would mean directing the offer to a separate segment;

4. Descriptors - they portray an offer usually in product / industry categories and are not sensu stricto; appear as a specific note with a smaller font next to the main brand;

5. Product brand - precisely presents a specific offer purchased by the consumer and is the result of a combination of the main brand and sub-brands (e.g. Toyota Aygo) or the main brand and descriptor (i.e. Mokate Cappuccino);

6. Umbrella brand - shows a group of products under one shared brand (e.g. Microsoft Office);

7. Branded differentiator - a name presenting a feature, component, service or program which aim is to make the offer more attractive with unique benefits / functions sought by consumers, which increases the attractiveness of impressions; it authenticates the promise made by the brand by giving the name a distinctive traits (e.g. the Quattro brand by Audi's four-wheel drive), it also helps to remember the distinctive attributes, differentiate the brand with others on the market;

8. Co-branding by brands owned by different entities (e.g. credit cards) - this offer uses two or more collections of associations created in the brands that sponsor them, which increases the degree of dissimilarity and acquiring customers.

\footnotetext{
${ }^{4}$ M. Dębski, Kreowanie silnej marki, Warsaw 2009, p. 11-12.

5 D. Aaker, Innovation: Brand it or Lose it, "California Review Management" 2017, Vol. 50, No 1.
} 


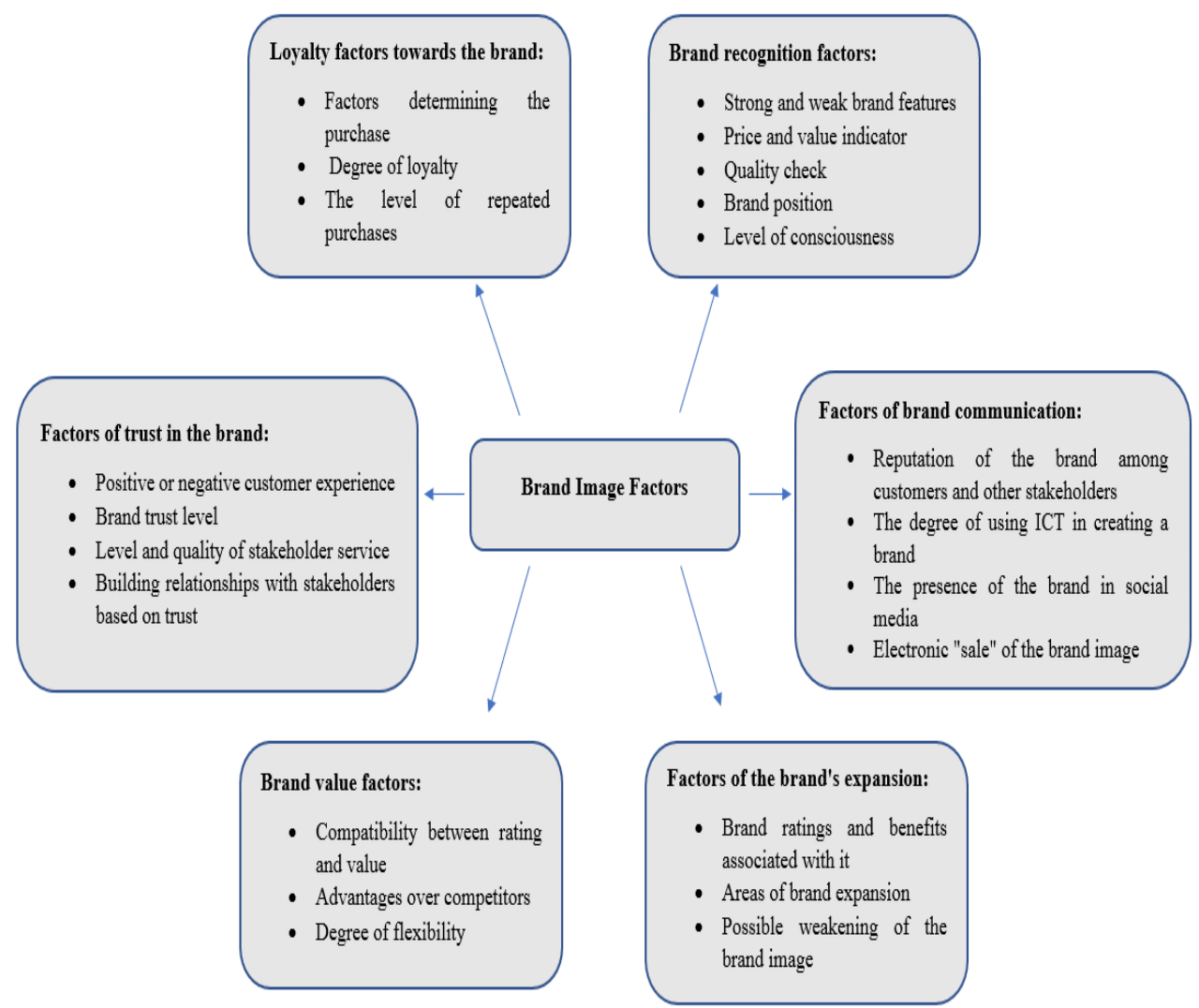

Figure 1. Factors determining the creation of the company's brand image

Source: own study based on: L. Bivainiene, Brand Image Conceptualization: The Role of Marketing Communication, "Economics and Management" 2007, Vol. 12, No 2, p. 12.

Continuing issues of Aaker it should be noted that "to be effective, a brand identity needs to resonate with customers, differentiate the brand from competitors, and represent what the organisation can and will do over time. When realised, the brand identity should help establish a relationship between the brand and the customer by generating a value proposition potentially involving functional, emotional or self-expressive benefits or providing credibility for endorser's brands"6.

What is more, while consumers interact with brands, they are exposed to different visual simulations such as a logo, colours, shapes, typefaces, characteristics, styles and other visual elements ${ }^{7}$. So these visual elements may come to be associated with the brand and serve

${ }^{6}$ A. Aaker \& E. Joachimsthaler, Brand Leadership, London 2000, p. 40-42.

${ }^{7}$ E.F. McQuarrie \& B.J. Phillips, It's not your father's magazine ad: Magnitude and direction of recent changes in advertising style, "Journal of Advertising", 37/2008, p. 95-106; J.E. Schroeder, Visual consumption in the image economy, In: "Elusive consumption". Ed. K. Ekstrom \& H. Brembeck, Oxford, UK: Berg 2004, p. 229-235. 
to identify it. Generally, it is vitally important to ensure one has a strong brand identity which is, not only consistent but also creates something which resonates in the mind of the consumer. In today's society, brands have become a vital part of most people's lives. Often, people recognise a particular product, design or logo. What the enterprise needs to do is to ensure the elements which people recognize are consistent and valuable. A brand identity is what makes a company unique and stand out ${ }^{8}$.

It should be emphasized that the significance of the brand usually increases as the wealth of the society increases. Customers basically do not pay for the goods; they pay rather for meeting the expectations related to the product. They expect prestige, well-being, recognition and social acceptance. It should be emphasized that in this context a brand is a combination of functional benefits of a given product with a specific added value. This value has an impact on the customer's perception of benefits. The owner of the brand does not create an image, but defines its identity, which he/she co-creates ${ }^{9}$. Real identity is the way in which managers see their brand, its features, its benefits, the values it represents. A desirable identity is a state that they would like to achieve, here are all their plans, goals, aspirations related to the brand. Image is an image in the minds of buyers. Identity is the beginning of the road, and the image of its purpose. All brands are created similarly, brand growth includes certain features: the brand must be distinct and different, which distinguishes it from its competitors, should be useful, it must enjoy respect, loyalty of consumers, and it should strive to achieve familiarity with its users ${ }^{10}$. What's more, the "creation" of a strong organizational brand minimizes the risk as well as the costs of maintaining clients. For example, a strong brand makes it possible to eliminate a number of risks, such as:

- financial, waste of money, if you buy a product that does not meet our expectations,

- product operation (functionality), uncertain results of use of an unknown brand,

- physical, potential possibility of causing physical harm to the buyer by an inappropriate product or service,

- social, levelling the risk of non-acceptance by the reference group for the choices made regarding the acquisition of goods and services,

- psychological, non-compliance of a given product with the image of its user,

- loss of time, risk related to the need to devote extra time to replace a good and/or service that did not work ${ }^{11}$.

In the case of a strong brand, an enterprise may use higher prices than the competition, increase demand on the market or create fast-paced groups of loyal consumers. A detailed summary of the benefits of the brand's strength for the company is presented in Table 1.

An important element in building a brand of enterprises is its architecture. The essence of the brand architecture concept is derived from the company's branding strategy, which aims to define common and diverse elements of the brand. Developing own structured brand portfolio structure is essential because it defines the relationship between the brands themselves, the company and the products or services ${ }^{12}$. The basis for building a brand portfolio is the decision to create one or many brands. A company can offer a wide range of products

\footnotetext{
${ }^{8}$ S. Killian, The importance of brand identity for environmental conservation brands, 2015, document on-line, (20.07.2018), p. 12-13.

9 J. Kall, Jak zbudować silna markę od podstaw, Gliwice 2006, p. 28.

10 E. Skrzypek, F. Pinzaru, Marka jako ważny..., p. 198-201.

11 J. Kall, Silna marka. Istota i kreowanie, Warsaw 2016, p. 19.

12 P. Kotler, W. Pfoertsch, Zarzadzanie marka w segmencie B2B, Warsaw 2008, p. 67-68.
} 
that are often not directly related to each other, they can direct their proposals to a specific group of buyers representing different preferences, or can they operate in markets with different geographical coverage ${ }^{13}$.

Table 1. Benefits of a strong brand in relation to enterprises

\begin{tabular}{|c|c|}
\hline Benefits & $\begin{array}{l}\text { Actions and elements of the company } \\
\text { to achieve the benefit }\end{array}$ \\
\hline $\begin{array}{l}\text { It distinguishes the enterprise from other offers of the orga- } \\
\text { nization }\end{array}$ & $\begin{array}{l}\text { Technological innovation } \\
\text { Product innovations } \\
\text { Marketing innovations } \\
\text { High quality } \\
\text { Developed marketing activities }\end{array}$ \\
\hline $\begin{array}{l}\text { It gives the chance to build customer loyalty, stimulates the } \\
\text { repeatability of sales of the company's products / services }\end{array}$ & $\begin{array}{l}\text { High quality } \\
\text { Decent price } \\
\text { Good reputation } \\
\text { Building trust in the company }\end{array}$ \\
\hline $\begin{array}{l}\text { It helps to prepare the company to enter its products on } \\
\text { separate market segments }\end{array}$ & $\begin{array}{l}\text { Marketing innovations } \\
\text { Developed marketing activities } \\
\text { Decent price }\end{array}$ \\
\hline Psychologically evaluates the image of the company & $\begin{array}{l}\text { Good reputation } \\
\text { Confidence in the company } \\
\text { High quality } \\
\text { Decent price }\end{array}$ \\
\hline $\begin{array}{l}\text { It enables company positioning on the market perception } \\
\text { map and in cyberspace }\end{array}$ & $\begin{array}{l}\text { Marketing innovations } \\
\text { Developed marketing activities } \\
\text { Technological innovation } \\
\text { Product innovations } \\
\text { Marketing innovations }\end{array}$ \\
\hline It stabilizes the market position of the company & $\begin{array}{l}\text { Good reputation } \\
\text { Confidence in the company } \\
\text { Current relations with stakeholders } \\
\text { Risk intelligence }\end{array}$ \\
\hline Supports the promotion of the company's products/services & $\begin{array}{l}\text { Good reputation } \\
\text { Marketing innovations } \\
\text { Developed marketing activities }\end{array}$ \\
\hline It is an element of the legal protection of an enterprise & $\begin{array}{l}\text { Legal regulations } \\
\text { Copyright protection } \\
\text { Risk intelligence } \\
\end{array}$ \\
\hline $\begin{array}{l}\text { Allows to set a higher price level and avoid price wars (based } \\
\text { on reputation) }\end{array}$ & $\begin{array}{l}\text { Good reputation } \\
\text { Confidence in the company } \\
\text { Current relations with stakeholders } \\
\text { Risk intelligence }\end{array}$ \\
\hline Increases bargaining power on distribution channels & $\begin{array}{l}\text { Developed marketing activities } \\
\text { Expanded distribution channels } \\
\text { Quality of logistics service }\end{array}$ \\
\hline
\end{tabular}

${ }^{13}$ M. Dębski, Kreowanie silnej marki, Warsaw 2009, p. 63. 
Table 1 (cont.). Benefits of a strong brand in relation to enterprises

\begin{tabular}{|c|c|}
\hline Benefits & $\begin{array}{l}\text { Actions and elements of the company } \\
\text { to achieve the benefit }\end{array}$ \\
\hline $\begin{array}{l}\text { Facilitates the introduction of new products to the market, } \\
\text { based on brand equity }\end{array}$ & $\begin{array}{l}\text { Good reputation } \\
\text { Confidence in the company } \\
\text { Current relations with stakeholders } \\
\text { Technological innovation } \\
\text { Product innovations } \\
\text { Marketing innovations }\end{array}$ \\
\hline $\begin{array}{l}\text { Gives an advantage over competitors (customers become } \\
\text { brand lawyers themselves) }\end{array}$ & $\begin{array}{l}\text { Good reputation } \\
\text { Confidence in the company } \\
\text { Current relations with stakeholders } \\
\text { Technological innovation } \\
\text { Product innovations } \\
\text { Marketing innovations }\end{array}$ \\
\hline $\begin{array}{l}\text { High demand for products of the brand-name company } \\
\text { allows using the effects of production scale }\end{array}$ & $\begin{array}{l}\text { High quality } \\
\text { Decent price } \\
\text { Good reputation } \\
\text { Building trust in the company }\end{array}$ \\
\hline
\end{tabular}

Source: own study based on M. Dębski, Kreowanie silnej marki, Warsaw 2009, p. 25.

The brand's architecture is shaped by marking, branding specific products and buying, selling or transferring brands. To a large extent, relationships between brands are the result of the values that brands deliver to buyers. The relationships between brands are often closely related to the brand name. It is the name that tangibly connects or removes the element of brands included in the portfolio. However, relationships throughout the brand constellation should go much deeper. The process of shaping the brand architecture is not limited to matching the proper name, but also emphasizes the role of the brand image, related values, or the functions that a given brand has to fulfil in the portfolio ${ }^{14}$. The layouts of possible relationships between brands are virtually unlimited. Their review is presented in Table 2, which is a reflection of the brand spectrum model by D. Aaker and E. Joachimsthaler, who considered the division criterion to take on the role of brands in the buyers' purchasing process and the impact they have on the competitiveness of the product. The range of possible architecture ranges from a collective brand (otherwise referred to as a branded house) to an individual brand (home of brands), between which one can distinguish many hybrid forms, usually referred to as sub-brands and supported brands ${ }^{15}$.

In the option of a brand house (collective brand), the same brand name covers various products with one or different identity. In the first case, products are subjected to a similar positioning process, in the second; the brands operate on different markets, so that each of them has an individual communication program and a specific promise for the buyer. The only "driver of the decision" of the consumer is the main brand, often identical with the name of the company ${ }^{16}$. In the brand home option (individual brand), individual products of the company are assigned exclusive brands. This option shapes independent brands of

\footnotetext{
${ }^{14}$ Ibidem, p. 65-67.

15 A. Aaker \& E. Joachimsthaler, Brand Leadership..., p. 40-50.

16 J. Kall, M. Hajdas, Zarzadzanie portfelem marek, Warsaw 2010, p. 36.
} 
Table 2. Relations between brands on the market

\begin{tabular}{|c|c|c|c|}
\hline \multirow{9}{*}{$\begin{array}{l}\text { Brand } \\
\text { relationship } \\
\text { spectrum }\end{array}$} & \multirow[t]{2}{*}{ House of brands } & No relationships & - Saturn (GM) \\
\hline & & Supporting from the shadow & - Lexus (Toyota) \\
\hline & \multirow[t]{3}{*}{ Endorsed brands } & Symbolic support & - Universal Pictures \\
\hline & & Core brand & - Nestea \\
\hline & & Strong support & - Obsession by Calvin Klein \\
\hline & \multirow[t]{2}{*}{ Subbrands } & $\begin{array}{l}\text { Comparable strength } \\
\text { of brands }\end{array}$ & - Gillette Mach 3 \\
\hline & & $\begin{array}{l}\text { The dominant role of the } \\
\text { collective brand }\end{array}$ & - Toyota Yaris \\
\hline & \multirow[t]{2}{*}{ Branded house } & Different identity & - GE Capital, GE Appliance \\
\hline & & One identity & - BMW, Apple \\
\hline
\end{tabular}

Source: A. Aaker \& E. Joachimsthaler, Brand Leadership..., p. 40-50.

individual importance, where each of them maximizes its influence and impact on the market, including specific territories. "Brand home" is the answer to the need to diversify the offer, so that the customer has a choice. The company can thus maximize market shares by dominating several segments. The failure of one of the brands does not entail others, nor does it spoil the image of the company itself. Sometimes, taking this strategy and launching more and more new brands on the market is to protect the image of the leading brand in the portfolio or defend against price war. „Brand home” also gives the chance of tactically blocking rivals in as many market segments as possible, and even blocking their access to distribution channels. There are many examples of intermediate variants between previously indicated extreme variants of brand architecture, which generally appear under the name of a supported brand. Its essence is that the brands present in the portfolio support the new offer, with the brand providing support being the brand representing the whole corporate entity. The company's brand is predestined to perform such a role when the enterprise itself is reliable in a given product category ${ }^{17}$.

\subsection{Loyalty of customers towards the brand}

"Closer to consumers" and "customer number one on sale" are terms known and commonly found in the environment offering "something" for sale. They reflect the prevailing conviction that the consumer is the determinant of decisions made regarding shaping the brands of goods / services and enterprises. In line with the principle of action - the reaction began to follow direct behaviour and customer voices, which were further indications for changes in the brand's life cycle, all in order to fulfil the role of the missing link in the market to bring benefits sought after by buyers. How buyers perceive a brand may decide to be or not to be in the sector. Hence the conviction that it is extremely important to look at the brand through the eyes of the customer, to be able to discover, create the essence of the brand and fully use it ${ }^{18}$.

${ }^{17}$ Ibidem, p. 55-59.

${ }^{18}$ H. Edwards, D. Day, Kreowanie marek z pasja, Kraków 2006, p. 20. 
Appreciation of the importance and impact of consumer loyalty on the capital of the commercial brand was a milestone in the history of marketing. Currently, nobody challenges the thesis that loyalty is one of the most important and most fruitful elements shaping the brand's value. At every step, the consumer meets with loyalty programs introduced by enterprises that have understood that it is more profitable to cultivate relationships with existing customers than to acquire new ones or to introduce new products whose failure rate is very high. Profits from loyalty are much more. Proponents of particular brands exist on the market as their free-willers, who also very often spontaneously praise and recommend their favourite brand to others. What's more, brand loyalty often becomes socially contagious, or "inherited" within the family, and even constitutes a kind of determinant of social status ${ }^{19}$.

Brand loyalty is a multifaceted phenomenon that provides the basis for stable sales in the future. The cores of loyalty are mainly communication elements, i.e. brand awareness and image. As the number of factors ensuring loyalty to the brand increases, its level increases. Elements that make up loyalty can be:

- repeatability, ritual of purchase of a given brand;

- satisfaction with the brand, positive evaluation;

- perception of brand change as a risky move;

- belief in the brand, pride in using a particular brand ${ }^{20}$.

A slightly different division of the motives of a strong link with a specific brand is presented by B. Kwarciak, pointing to elements such as the desire to avoid unnecessary cognitive effort, avoidance of risks, especially social, cohesiveness of behaviours, prestige and stimulation. The last aspect is a real paradox, because loyalty understood, among others, as reducing the emotional stimuli of the client, it also requires delivering newer and newer impressions through the brand that the client has chosen. At the same time, when along with excessive stimulation it loses the remaining benefits; it will lead to a change in the product's brand $^{21}$. This is, therefore, a fairly dangerous balance that consumers are forcing businesses to do.

Loyalty is the result of the clients learning that a given brand meets its individual needs and provides them with unique benefits. Often, the favoured brand also reflects the buyer's image, fits the personality and thus becomes valuable to customers. Loyal consumers can acquire a brand, although it is more expensive than others or harder to find, because they perceive it as more valuable, better. The strength of brand loyalty is inversely proportional to the effectiveness of competition (the importance of actions decreases when consumers are more loyal to the brand chosen $)^{22}$.

In addition to factors enhancing brand loyalty, which directly refer to the customer (endogenous factors), there are so-called exogenous factors that exist outside of consumers. These include, for example, brand features, the width of the company's assortment, the quality of products, services or the degree of market saturation. Loyalty factors, therefore, depend not only on the characteristics of the brand itself and the consumer, but also on factors

19 B. Kwarciak, Wygodna klatka dla klienta, „Modern marketing” 1999, No. 5/1999, www.modernmarketing.pl, (26.02.2018), p. 1.

${ }^{20}$ Ibidem, p. 2-3.

21 J. Kall, R. Kłeczek, A. Sagan, Zarządzanie marką, Kraków 2006, p. 13.

${ }^{22}$ M. Dębski, Kreowanie silnej marki..., p. 40. 
such as the social environment or market conditions ${ }^{23}$. However, consumers can make a decision to buy a given brand under the influence of their current habits, low price, lack of other offers or their too high availability, while not being faithful to the product they use and not treating it as exceptional. It is necessary to distinguish loyalty from the habit of purchasing, because the phenomenon of re-purchasing a product of the same brand does not indicate consumer loyalty ${ }^{24}$.

\subsection{Intelligent enterprise and the creation of own brand}

According to the literature the first descriptions of the intelligent organization took place in the 1990s in the publications of G. Pinchot and E. Pinchot, as well as J.B. Quinn. According to the first two authors, the requirement for an intelligent designation is to use the intelligence of their employees ${ }^{25}$. By contrast, according to J.B. Quinn ${ }^{26}$ intelligent organization transforms intellectual resources into a service chain that creates an offer for a certain group of customers with the most useful features. What is more, B. Dayyani ${ }^{27}$ considers the intelligent organization to be the one that managed to create a knowledge base and competitive advantage in the area of customer value creation and information input. A number of interpretations of the concept of intelligent organization exist in the literature of the subject. It is also worth noting that the various aspects of its functioning are exposed, starting with the management of human capital, through learning, knowledge acquisition, and ending with gaining competitive advantage on the market ${ }^{28}$.

Generally, in the in the global research practise many scholars stated that the structural architecture of an intelligent organization is flexible and responsive, shifting to meet new challenges and current situations. What makes it flexible is not the brilliance of organizational designers sitting at the top, but the free choices of people in the middle and bottom of the organization choosing the connections needed to make their particular enterprises thrive while developing synergistic integration with what is going on elsewhere. Therefore, intelligent organizations, in fact, operate as systems in which every employee sees his or her role in the context of a system of roles and defined outcomes that comprise in total the nature of their association's mission and purpose. Seeing their products, projects, and contributions in the context of an organization wide system allows all employees to channel their collective energies in the same direction. Besides, intelligent enterprises combine three aspects of being on the market: delivering of value for internal and external stakeholders, managing risk connected with the activity on the turbulent market, and managing relation-

${ }^{23}$ P. Kwiatek, Programy lojalnościowe: budowa i funkcjonowanie, Warsaw 2007, p. 38.

${ }^{24}$ J. Kall, R. Kłeczek, A. Sagan, Zarzqdzanie marka..., p. 25-26.

${ }_{25}$ G. Pinchot, E. Pinchot, The Intelligent Organization, "Executive Excellence" 1990, No. 7(12), p. 19.

26 J.B. Quinn, The Intelligent Enterprise a New Paradigm, "The Academy Of Management Executive" 1992, No. 6(4), p. 48.

27 B. Dayyni, Structured Analytics: The Creation of the Intelligent Organization, "World Academy of Science, Engineering and Technology" 2009, No. 38, p. 97.

${ }^{28}$ H. Godlewska-Majkowska, Inteligentna organizacja - dystrybucja wiedzy, kompetencje pracowników, miejsce na rynku, Warsaw 2013, p. 11. 
ship with different groups of stakeholders ${ }^{29}$. Continuing the evolution of intelligent enterprise is about creating a future organization based on creation of the good image, excellent brand, creativity and improvement of human capital. In general, the specific characteristics of an intelligent enterprise can be defined by its features (Fig. 2).

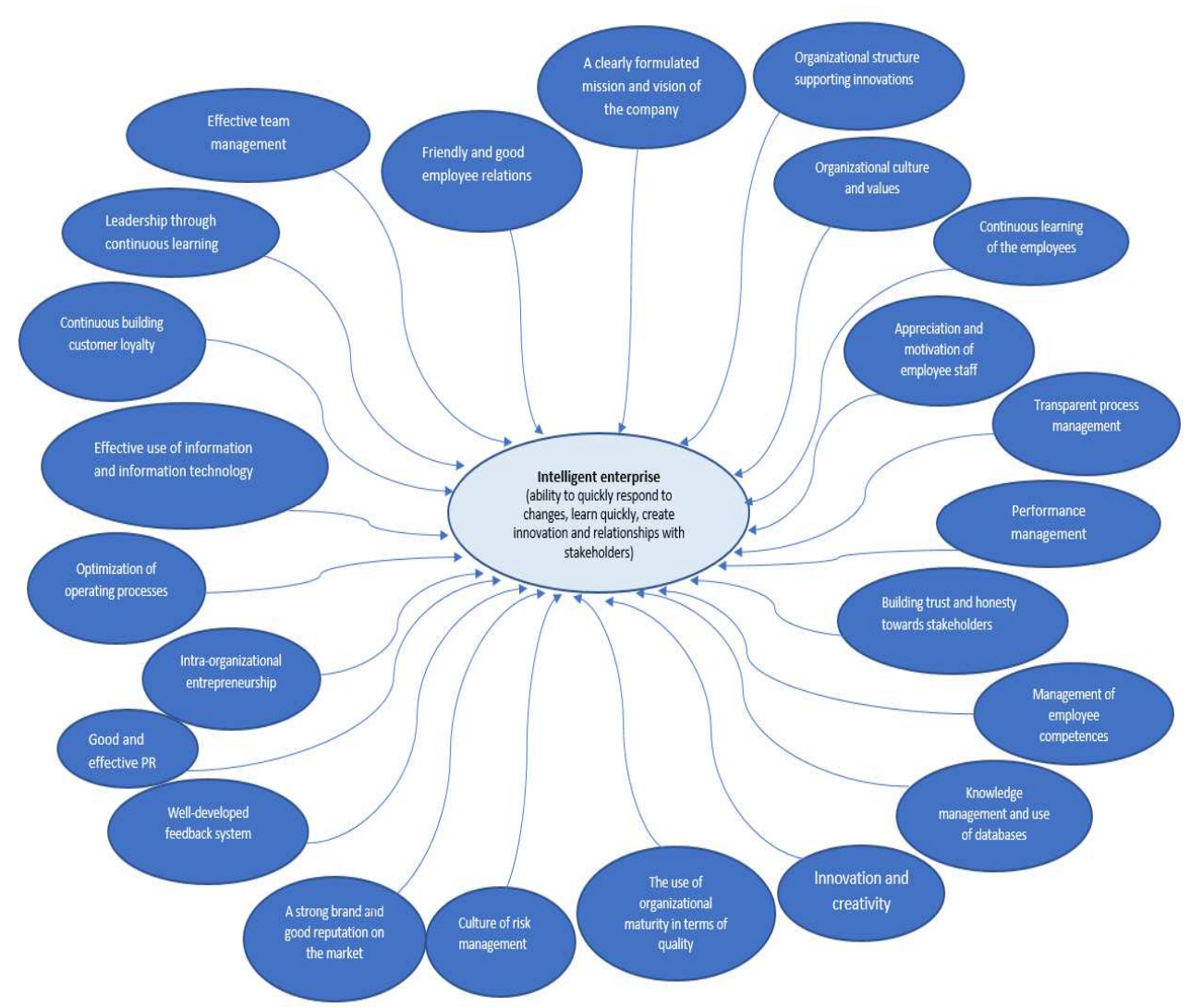

Figure 2. Features of the intelligent enterprise

Source: own study based on: P. Sydänmaanlakka, An Intelligent Organization. Integrating Performance, Competence and Knowledge Management, Capstone Publishing Limited, Oxford 2002, p. 168; W. Wereda, J. Woźniak, Kryterium ryzyka w organizacji “zwinnej”, „Nowoczesne Systemy Zarządzania" 2015, No. 10, p. 65; Report "Rewriting the rules for the digital age. 2017 Deloitte Global Human Capital Trends", Deloitte University Press (03.01.2017), p. 25.

As it can be noted in the figure 2 the presented framework introduces the basic features for creating the intelligent enterprises. There are many aspects of internal and external process engaged in the activity. Knowledge management along with investing in human factor

${ }^{29}$ W. Wereda, J. Paliszkiewicz, I.T. Lopes, J. Woźniak, K. Szwarc, Intelligent Organization (IO) towards contemporary trends in the process of management - selected aspects, Military University of Technology, Warsaw 2016, p. 35-37. 
and initiating creative, innovative processes, good relation with employees and team work based on talents in the organization are the foundations of building human recourse friendly management model and effective structures (organizational culture, mission and vision). More can be found outside the enterprise as the model that stands out from the learning organization through increased operational flexibility, high adaptability to changes in the environment, development of an early warning system (culture of risk management), and blurring of organizational boundaries as well stakeholder relationship management processes (creation of the well-known brand, the good reputation etc.).

The formation of an intelligent enterprise requires many efforts and abilities from the organization, that is adapting to the environment based on continuous learning, creativity, taking into account new challenges resulting from qualitative and quantitative changes in the company's resources, acceptable risk, social and ecological acceptance, as well as creating trust and long-term relationships with stakeholders (Table 3).

Table 3. Elements shaping the intelligence of a modern enterprise

\begin{tabular}{|c|c|}
\hline Type of intelligence & Definition \\
\hline Technological intelligence & $\begin{array}{l}\text { expressed in skilful creation, acquisition and use of appropriate } \\
\text { technologies and their continuous improvement in order to obtain } \\
\text { high quality products and develop new production areas }\end{array}$ \\
\hline Innovative intelligence & $\begin{array}{l}\text { perceived as a constant search for innovative solutions, as well as } \\
\text { creating favourable financial, motivational and psychosocial con- } \\
\text { ditions to promote innovation and creative behaviour of employees }\end{array}$ \\
\hline Social intelligence & $\begin{array}{l}\text { expressing concern for people, constant improvement of working } \\
\text { conditions, pay, promotion, delegation of rights }\end{array}$ \\
\hline Organizational intelligence & $\begin{array}{l}\text { expressing itself in the ability to adapt the organization to changed } \\
\text { tasks, creating simple, flexible structures, independently operating } \\
\text { and ensuring excellent internal communication }\end{array}$ \\
\hline Financial intelligence & $\begin{array}{l}\text { running in skilful financial management, their rational division and } \\
\text { spending on current goals and investments aimed at improving the } \\
\text { conditions of the company's operation in the future }\end{array}$ \\
\hline Marketing intelligence & $\begin{array}{l}\text { expressed in a constant market research, quick perception of cus- } \\
\text { tomers' needs and wishes, ability to search for market niches and } \\
\text { enter new markets }\end{array}$ \\
\hline Ecological intelligence & $\begin{array}{l}\text { expressing special concern for environmental protection, reduction } \\
\text { of harmful emissions and activities }\end{array}$ \\
\hline $\begin{array}{l}\text { Intelligence to acquire } \\
\text { knowledge and data }\end{array}$ & $\begin{array}{l}\text { expressing mainly with the ability to create and acquire knowledge } \\
\text { quickly as well as to form appropriate databases to improve the en- } \\
\text { terprise's processes }\end{array}$ \\
\hline Risk intelligence & $\begin{array}{l}\text { the ability to more accurately distinguish between extreme proba- } \\
\text { bilities of an opportunity or risk in terms of risk when making ra- } \\
\text { tional decisions - however, extremely hazardous from the point of } \\
\text { view of the environment, but "intelligent" from the point of view } \\
\text { of the person taking the risk. }\end{array}$ \\
\hline Intelligence of trust & $\begin{array}{l}\text { the ability to solidly create an aspect of trust "in the eyes" of all } \\
\text { stakeholders through specific processes and characteristics of the } \\
\text { enterprise, i.e. creating an image of a friendly employer, the relia- } \\
\text { bility in sales, maintaining a certain level of quality of products/ser- } \\
\text { vices, a quick response to consumer complaints, etc. }\end{array}$ \\
\hline
\end{tabular}


Table 3 (cont.). Elements shaping the intelligence of a modern enterprise

\begin{tabular}{|l|l|}
\hline \multicolumn{1}{|c|}{ Type of intelligence } & \multicolumn{1}{c|}{ Definition } \\
\hline $\begin{array}{l}\text { Intelligence of partnership and } \\
\text { building relationships }\end{array}$ & $\begin{array}{l}\text { the ability to establish partnership in the field of cooperation with } \\
\text { both business and the public sector as well other entities, and the } \\
\text { recognition as a strategic goal of maintaining long-term relation- } \\
\text { ships with internal and external stakeholders. }\end{array}$ \\
\hline
\end{tabular}

Source: own study based on W.M. Grudzewski, L.K. Hejduk, Przedsiębiorstwo przyszłości, Warsaw 2011. p. 99-100; W. Wereda, Koncepcja value innovation jako fundament organizacji opartej na innowacyjności i relacjach z interesariuszami $[\mathrm{In}]$ Mapa ryzyka w zarzadzaniu organizacja. W kierunku organizacji opartej na innowacjach i kulturze ryzyka. Studia przypadków oraz dobre praktyki, Ed. J. Wozniak, W. Wereda, Warsaw 2018, p. 92-93.

Summarizing, the process of creating the intelligent enterprise is long-lasting but is must be followed by all the members of the organization. That is why; the management of such organizations recognizes that the priority is to educate and improve people, and to prepare individual pathways for the development of employees in order to liberate their creative potential in individual and collective activities. What is more, the strength of intelligent enterprises is to increase the efficiency of processes, activities and communications. Organizational solutions such as limiting control and leaving employees with a high degree of freedom are what they do, which in turn creates engagement and fosters the development of the creative potential of employees. Furthermore, sources of success can be found in the continuous implementation of the rapid learning process, as well as the ability to transform information into knowledge, constant updating, renewal and creation of new knowledge resources, determine the competitive advantage of these organizations. In a broad context, knowledge management in intelligent enterprises enables to develop the skills to effectively adapt to changing of internal and external conditions. Through the use of intelligence, it is possible to understand the configuration of phenomena, trends in the changing environment, which is about the ability to use opportunities and avoid threats. Intelligent organizations are characterized not only by their ability to achieve distinctive results from the competition, but also by their ability to maintain market position over a long period of time ${ }^{30}$. By such processes the intelligent enterprise creates own brand based on continuous learning, the high quality of products, quick reactions for the differentiated environment and the good reputation and image in the eyes of stakeholders.

\subsection{Building relationships with stakeholders based on the strong brand}

A contemporary enterprise is above all a complex system characterized by flexibility and agility in the understanding of its adaptation capabilities, adequately to changing conditions. Agility is de facto conditioned by the flexibility of the process structure and the extraction of these components from it, which foster a dynamic reorientation of tasks and their contractors according to the criterion of competence and the availability of time and space for various types of resources. The higher the level of integration of specific objectives (defined from the stakeholder's side) with global goals, the higher the synergistic effect of the entire multi-entity system. Integration is not only the care for consistency of operation

${ }^{30}$ W. Wereda, J. Paliszkiewicz, I.T. Lopes, J. Woźniak, K. Szwarc, Intelligent Organization (IO)..., p. $10-11$. 
in the conditions of changeability of the environment and the related flexibility of a given entity, but also the maximum use of own and foreign potential. That is why, to maintain intelligent processes and create the strong brand each enterprise needs to keep long-lasting relationships with stakeholders that can be defined as specified groups, institutions, persons that have influence on functioning and achieving goals by the entity, and they are interested in activities of the enterprise on different level and context $\mathrm{t}^{31}$.

Maintaining a stakeholder in an organization is nothing more than building a continuous contact with one, which can turn into a long-term relationship. An important fact is defining the factors that cause stakeholder satisfaction and satisfaction with the product or after using a given service over a long period. According to the contemporary literature on the subject, for example keeping existing clients is easier than acquiring new ones. This is influenced by such aspects as:

- the stakeholder gained earns its loyalty during each transaction or contact;

- loyalty is built through the stakeholder satisfaction that has already benefited from the enterprise's services/goods or activities;

- the staff that serves the stakeholder is the guiding element in building trust;

- the value of the enterprise is created by satisfied and loyal stakeholders (employees, clients, providers, distributors etc.);

- high internal quality and solid motivation of employees allows better customer service $^{32}$.

Stakeholders can be divided into two main groups from the point of view of the division into the surroundings: those belonging to the internal environment and those belonging to the external environment. In addition, according to the concept of stakeholders, there are two basic dimensions characterizing the relationship between the organization and individual groups of the environment, i.e. the potential for conflict and the potential for cooperation. Depending on the nature of mutual relations, organizations develop different strategies for managing contacts with specific stakeholder groups ${ }^{33}$.

The human factor in contemporary organizations can be seen through the prism of a specific "leverage of the level of intelligence". These are employees at various levels (including designers and managers), owners and other stakeholder groups, including as a result of undertaking project-improvement activities of a passive or active character, make the organization an entity "living" in the environment, being able to adapt to this environment and shape the surrounding, for example through direct and effective communication with the customer to shape the brand image company. On the other hand, returning to the issue of the organization's relations with stakeholders, it is worth mentioning that these relations constitute the structure and current state (e.g. in the context of development capability, financial liquidity, credibility in the eyes of clients and partners, competitive potential, or the capacity of market communication channels) organization. Interactions combine dif-

${ }^{31}$ R.E. Freeman, Strategic Management: A Stakeholder Approach, Boston 1984, p. 21; W. Wereda, J. Paliszkiewicz, I.T. Lopes, J. Woźniak, K. Szwarc, Intelligent Organization (IO).., p. 28.

32 P. Bartkowiak, Sukces przedsiębiorstwa a zarzadzanie wartościa klienta, „Zarządzanie i Finanse” R. 11, No. 4/ 2, 2013, p. 9-10.

${ }^{33}$ S. Kasiewicz, W. Rogowski, M. Kicińska, Kapitat intelektualny. Spojrzenie z perspektywy interesariuszy, Krakow 2006, p. 72-73; D. Mirońska, Relacje z interesariuszami organizacji non profit z perspektywy marketingowej, Warsaw 2016, p. 81-85. 
ferent categories of resources (e.g. human resources are combined with information, material or financial resources creating relational resources). Thus, a look at changes in the conditions of the functioning of the organization and cooperation from the perspective of relations with stakeholders seems to be a legitimate activity (Table 4). What's more, changes in the conditions of the organization's functioning combine the perspectives of the internal and external environment. It is difficult to classify a specific trend or phenomenon only to one of the indicated planes of the environment. It results from the systemic and network character of relations in the context of social and economic life. For example, changes in legal

Table 4. Building relations with stakeholders in the process of contemporary changes in organizational and market conditions

\begin{tabular}{|l|l|}
\hline \multicolumn{1}{|c|}{ Relations with internal stakeholders } & \multicolumn{1}{|c|}{ Relations with external stakeholders } \\
\hline $\begin{array}{l}\text { Moving towards modern business models, referring to } \\
\text { crowdfunding, crowdsourcing, born global model, } \\
\text { "empty" / "invisible" organizations, virtual structures, } \\
\text { etc.). }\end{array}$ & $\begin{array}{l}\text { The increase in the importance of regulation on } \\
\text { a global scale and increasing the scope of their }\end{array}$ \\
$\begin{array}{l}\text { Increased importance of innovation processes in the de- } \\
\text { velopment of the organization and selection of the right } \\
\text { impact on the organization's activities. }\end{array}$ \\
$\begin{array}{l}\text { strategy for creating innovation (innovations vs. imita- } \\
\text { tions). }\end{array}$
\end{tabular}

Source: J. Wozniak, W. Wereda, Mapa ryzyka w zarzadzaniu organizacja. W kierunku organizacji opartej na innowacjach i kulturze ryzyka. Studia przypadków oraz dobre praktyki, Warsaw 2018, p. 15. 
regulations determine the behaviour of employees and managerial staff, the activities of producers / designers can cause modifications in customer reactions, as well as the activities and experience of the organization's management staff (being the market leader) may determine changes in competitors 'or partners' strategies (e.g. providers of outsourcing services). The network of relations and the resources associated with them simultaneously determine the level of experience of all stakeholders and reflect the complexity of processes influencing the creation of the image of the organization's brand in the enterprise itself and in its environment ${ }^{34}$.

In creating the strong brand in the enterprise it is vital to find loyal customers and then to maintain them by the organisation. According to practitioners and theoreticians, managing a one-off, a new client is much more expensive than focusing on those present one. Therefore, the relationship with a loyal customer should be multistage and it is extremely important to contact the customer after the transaction. Thanks to this, one can shape further offers for specific needs, find out what the customer considers an advantage and what a disadvantage. It is also worth, if complicated, prepare for packages that will reward inappropriate customer service. In this case, the client will definitely appreciate the company's efforts and will return in the future, letting go of the unpleasant event. ${ }^{35}$ Therefore, effective building of customer relations requires compliance with several principles, which are described by A. Dejnaka ${ }^{36}$ :

1. Concentration on customer maintenance, i.e. taking care of already acquired customers and monitoring their needs; sometimes the company itself should also be able to anticipate future consumer needs. Henry Ford said that if at the turn of the 19th and 20th century he asked people what their transport needs were, they would probably reply that they need faster horses. Nobody, however, would say that he/she needs a car.

2. Lifetime profit. The client's value for the company is not determined by the size of the last transaction, therefore the company should focus on making the client make as many transactions as possible for the longest possible time.

3. Applying post-transaction service, that is, contacting the customer after the transaction, which increases the client's confidence in the company and builds its loyalty; post-trade contact is also an excellent opportunity to gather information about the needs and expectations of the client.

4. Involving clients in the company's affairs. Establishing long-lasting relationships with clients is not possible without building their commitment, which is why you need to engage clients in activities for the company (e.g. in recommending products or completing surveys), and then rewarding them for taking these actions. In this way, the company will match the goods / service to the customer's needs and consumers will become actual co-creators of the company's products (prosumers).

${ }^{34}$ J. Wozniak, W. Wereda, Mapa ryzyka w zarządzaniu organizacją..., p. 15-16.

35 A.K. Mazurek-Kusiak, Wptyw dziatań marketingowych matego przedsiębiorstwa na zadowolenie klientów z jakości ustug na przykładzie biura podróży, „Pismo Środowiska Badaczy Problemów Rynku: handel wewnętrzny, rynek, przedsiębiorstwo, konsumpcja, marketing” 2013, Vol. 2, No. 3, p. 226.

36 A. Dejnaka, Budowanie relacji z klientem [In:] Biblia e-biznesu, Ed. M. Dutko, Publishing House Helion, Gliwice 2013, p. 393-400. 
5. Help in making decisions. Not every customer knows exactly what product came to the store, so the help of customer service staff can be invaluable in this case. Today, you can also use automated help for this (e.g. chatbots).

6. Maintaining constant two-way communication with the client. The company cannot be deaf to messages from the client. The company must respond to changes in the client's needs and expectations, as well as inform him about new products and services on offer.

7. Customization or matching the product to the customer's needs. A good example of customization is Dell or Apple. Ordering computers over the Internet in this company consists in the fact that customers choose the parameters in which their equipment is to be equipped. In this way, customers can not only choose, but almost create products best suited to their needs.

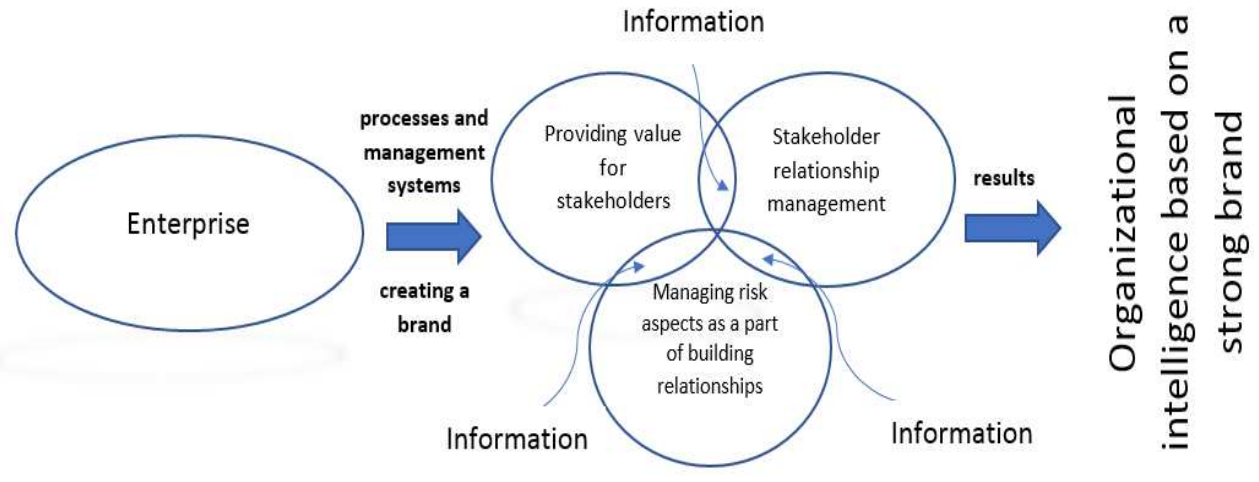

Figure 3. The combined elements of the success of the modern enterprise in the direction of "organizational intelligence" based on the process of creating a strong brand

Source: own elaboration based on: L. Bourne, Stakeholder relationship management. A maturity model for organisational implementation, Gower, Farnham 2009, p. 17.

Modern organizations are increasingly focused on the issues of so-called value networks, or networks of organizations that combine information flows and privileged relationships, enabling cooperation in the process of creating and providing value to stakeholders, and especially customers, to create their right image on the market. Of course, the risk is also an important element in this process by each party. Figure 3 presents the interrelationship between three elements, such as: providing value to stakeholders, managing risk aspects in relation to building relationships and managing relations with stakeholders. The key to effective management of a modern enterprise are: information, communication, effective processes and management systems, reporting on the supply of value, and the process of branding in the eyes of stakeholders, both internal as a good employer and external as a model trading partner on the market. Value delivery is measured and reported via reporting mechanisms. Successful implementation of processes in an enterprise depends on 
the understanding of the operating system, which assumes that the development of successful results for the organization requires the simultaneous management of all three factors ${ }^{37}$ - which ultimately leads to the creation of so-called. "Organizational intelligence" based on the creation of a strong brand on all levels.

\section{APPLE AS THE BIGGEST BRAND OF THE INTELLIGENT ENTERPRISE - A CASE STUDY}

\subsection{Short history}

According to many literature sources Apple is one of the leading and most valuable companies in the world, which consistently follows the path of permanent innovation, as well as built a leading position among global brands in the electronics industry. The company's activities are focused on both creating new markets and giving value to innovation and a new pace on existing ones. Apple was founded as a result of cooperation between Steve Jobs and Stephen Wozniak. What is surprising in 1976, both men started their activities in Jobs' bedroom, moving it to the garage. In the same year, a personal Apple I computer was created, which cost 666.66 dollars, and it was produced in 200 copies. A year later, Apple II was created, which was already mass-produced. The successor was easier to use and had more functions. The second model was the basis for education in the 80 's and 90 s $^{38}$. Over the next years, an Apple III computer was created for business, as well as an enhanced Apple IIe and an Apple Lisa computer. Over the last, Jobs did not work, so he took care of the project called Macintosh and the history started to be very vital for the company until 1985, when Steve Jobs left Apple for 10 years, after quarrel with another employee. Apple was in an increasingly bad financial condition. Subsequent products were not successful and were not popular among customers. In addition, Microsoft released the Windows 3.0 market, which became a direct rival of Apple. The advantage of Microsoft was the fact that the software was compatible with products from various, cheaper manufacturers ${ }^{39}$. Apple regained good standing only when Jobs returned as the operations director. Already in 1998, the founder released a computer that was given the name iMac. On the computer market, it turned out to be a revolution, and moreover, as many as 800,000 iMac computers were sold over 139 days $^{40}$. Since the return of Steve Jobs, Apple's shares have increased sevenfold. The founder himself did not want to take over any packet of shares. But if he did, after a short time his stock would reach $\$ 400$ million $^{41}$. The next big steps Apple made in 2007 launching the first iPhone, and in 2010 the $\mathrm{iPad}^{42}$. In 2011, Steve Jobs died, leaving Apple with a value of over 300 billion dollars. The power over the company was taken over by one of the trusted employee - Timothy D. Cook, who was responsible for minimizing costs and simplifying production processes ${ }^{43}$.

\footnotetext{
37 L. Bourne, Stakeholder relationship management..., p. 20-21.

38 www.applecenter.pl (30.06.2018).

39 D. Primack, Fallen Apple: Steve Jobs resigns. retrieved from CNN, August 24/2011.

${ }^{40}$ www.applecenter.pl (30.06.2018).

${ }^{41}$ W. Isaacson, Steve Jobs. Simon\&Schuster, New York 2011.

42 www.apple.com (30.06.2018).

43 www.applecenter.pl (30.06.2018).
} 


\subsection{Apple and its brand}

As it is presented in many technology journals, the company deals in the design and production of consumer electronics, software and personal computers. In recent years, thanks to new business models, created in the direction of building a specific culture on the market and innovative rules of competition in the IT industry, Apple has become the most recognized global brand. Due to the report the "BRANDZ TOP. 100 most valuable global brands in 2018" the Apple brand is gaining in value both from the investors' point of view, customer experience and other stakeholders. It is generally seen that the rise of technology is most apparent in the 12-year change of the Top 10 ranking. All but two brands are technology-related in 2018, compared with only four brands in 2006 (figure 4). The company has worked on its brand for years introducing different aspects of loyalty towards different stakeholders, for example with customers (good quality, easiness of use, prestige of having such products etc.), employees (good and well-paid jobs, possibilities of development, acceptance of working with minorities etc.), providers (good contracts based on satisfied prices and conditions, settlements on time etc.).

\begin{tabular}{|c|c|c|}
\hline & 2006 & 2018 \\
\hline 1 & Microsoft & Google \\
\hline 2 & $(8)$ & \\
\hline 3 & cocrboln & amazon \\
\hline 4 & 中国移动 & Microsoft \\
\hline 5 & Marlhoro & Tencent 腾讯 \\
\hline 6 & Walmart: :s & facebook \\
\hline 7 & Google & VISA \\
\hline 8 & 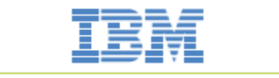 & M. McDonald's \\
\hline 9 & clt & C2Allbaba Group \\
\hline 10 & TOYOTA & $\underbrace{}_{\text {AT\&T }}$ \\
\hline
\end{tabular}

Figure 4. List of top 10 global brands in 2006 and 2018

Source: Report “BRANDZ TOP. 100 most valuable global brands in 2018”, Kantar Mill Ward Brown. Retrieved from www.brandz.com (30.06.2018), p. 22.

During the market evolution the organization implemented new inventors, thanks to which it could enter new markets, e.g. TV or mobile payments, all the time activities and investments were carried out in the development of key products such as personal computer, iPod or iPad. The company itself presents its offer in the Annual Report, which shows that 
“Apple Company designs, manufactures and markets mobile communication and media devices and personal computers, and sells a variety of related software, services, accessories, networking solutions and third-party digital content and applications. The Company's products and services include iPhone ${ }^{\circledR}$, iPad $\AA$, Mac $®$, Apple Watch ${ }^{\circledR}$, Apple TV®, a portfolio of consumer and professional software applications, iOS, macOS $®$, watchOS $®$ and tvOS ${ }^{\mathrm{TM}}$ operating systems, iCloud ${ }^{\circledR}$, Apple Pay ${ }^{\circledR}$ and a variety of accessory, service and support offerings. The Company sells and delivers digital content and applications through the iTunes Store ${ }^{\circ}$, App Store ${ }^{\circledR}$, Mac App Store, TV App Store, iBooks Store ${ }^{\circledR}$ and Apple Music ${ }^{\circ}$ (collectively "Digital Content and Services")" 44 .

Due to the specificity of the industry, characterized by a high rate of technological change, the competitive advantage of the company depends primarily on its ability to maintain an appropriate innovative rhythm and customer experience. A key element of Apple's strategy is the continuous launch of new products and services on the market, as well as the development of technologies that support both the company's existing offer and create new business opportunities ${ }^{45}$. According to the Annual Report the company describes its business strategy in few statements: "The Company is committed to bringing the best user experience to its customers through its innovative hardware, software and services. The Company's business strategy leverages its unique ability to design and develop its own operating systems, hardware, application software and services to provide its customers products and solutions with innovative design, superior ease-of-use and seamless integration. As part of its strategy, the Company continues to expand its platform for the discovery and delivery of digital content and applications through its Digital Content and Services, which allows customers to discover and download digital content, iOS, Mac, Apple Watch and Apple TV applications, and books through either a Mac or Windows personal computer or through iPhone, iPad and iPod touch ${ }^{\circledR}$ devices ("iOS devices"), Apple TV and Apple Watch. The Company also supports a community for the development of third-party software and hardware products and digital content that complement the Company's offerings. The Company believes a high-quality buying experience with knowledgeable salespersons who can convey the value of the Company's products and services greatly enhances its ability to attract and retain customers. Therefore, the Company's strategy also includes building and expanding its own retail and online stores and its third-party distribution network to effectively reach more customers and provide them with a high-quality sales and post-sales support experience. The Company believes ongoing investment in research and development ("R\&D"), marketing and advertising are critical to the development and sale of innovative products, services and technologies"46.

\subsection{The company's technology market}

In the literature on the subject, Apple is presented as an "exception confirming the rule", because the company rejects the egalitarianism of society and their concept of "crowd wisdom", adopting an elitist rule, which consists in low transparency of the company for the outside world. The organization is reluctant to disclose information about its activities, the development of new products and the participation of third parties in this process, which is

\footnotetext{
${ }^{44}$ Annual Report of Apple Inc. 2017, retrieved from www.apple.com, p. 4.

${ }_{45}$ M. Roszkowska-Menkes, Otwarte innowacje: w poszukiwaniu równowagi, Warsaw 2015, p. 199.

${ }^{46}$ Annual Report of Apple Inc. 2017, retrieved from www.apple.com, p. 4.
} 
why this approach is often called "walled-garden" 47 . It is based on the fact that Apple creates devices and software, fully controlling access to external API entities and the architecture of each of its products, and operating systems created by the company operate only on its devices, all applications can be operated only by these systems and only in these systems can be created ${ }^{48}$. Fry claims that Steve Jobs's assumption was very much in the company's competitive advantage in terms of such a technology process, because a closed, confidential process allows creating such efficient "user-friendly" and stylish devices. In addition, "true innovation" means looking into the future, anticipating needs that no one has ever thought about, and then providing solutions that redefine the current new product categories ${ }^{49}$.

Apple acknowledges that many of its products are partly based on the intellectual property of external entities from which the organization buys licenses or patents ${ }^{50}$. Apple decides to buy technology or outsource some of the research and development activities primarily in relation to those elements of the value provided to consumers, which are the least important from the point of view of its competitive advantage. For example, Apple decided to cooperate strategically with Intel due to the fact that customers value computers not as microprocessors inside, but for a user-friendly interface and a functioning operating system $^{51}$. The company uses the architecture of ARM processors in its mobile devices and Apple TV. The outsourcing also covered the process of designing Apple notebooks and creating, testing and maintaining software - in this respect the company cooperates with Indian companies Infosys and Wipro ${ }^{52}$. However, Jobs, a long-time company leader, was of the opinion that in order to succeed, employ outstanding people who want to do the best in the world ${ }^{53}$, and support licensing and intellectual property from external entities. For this purpose, Apple annually maintains a high level of expenditure on research and development (about 2-3\% of sales). Due to the global dissemination of products and the brand itself, the volume of sales increases from year to year on different continents (table 5).

\subsection{Building relationships with clients as main stakeholders of Apple}

Apple is one of the few companies that actually embody the values, quality and innovation proclaimed. Proof of this can be long queues of customers setting up in front of the stores on the day of the release of the latest products. Apple focuses on simple solutions in an original housing. The best example is the iPad and iPhone. Due to the values that the company has been following in the creation of its products, there are as many as 25 exhibits of this brand in the Museum of Modern Art in New York ${ }^{54}$. Apple is a customer-oriented brand. A perfect example is the iPod with software and service. Digital music recording has

\footnotetext{
${ }^{47}$ S. Fry, Steve Jobs, 2011, retrieved from www.stephenfry.com (30.06.2018).

${ }_{48}$ M. Roszkowska-Menkes, Otwarte innowacje..., p. 200.

49 S. Fry, Steve Jobs, $2011 \ldots$

50 Annual Report of Apple Inc. 2017, retrieved from www.apple.com, p. 9.

${ }^{51}$ K.R. Lahkani, H. Lifshitz-Assaf, M.L. Tushman, Open innovation and organizational boundaries. The impact of task decomposition and knowledge distribution on the Locus of Innovation, Working paper 12-057/2012, Harvard Business School, May.

${ }_{52}$ P. Mishra, Apple CIO O'Connor visited Bangalore in January: Will it be iNDIA after iPhone, iPad?. "The Economic Times"2012, retrieved from www.bit.ly (20.07.2018).

${ }^{53} \mathrm{~K}$. Bhasin, Hire people who want to make the best things in the world. Business Insider. 25.08.2011, retrieved from www.bit.ly.

${ }^{54}$ S. Lachowski, Droga ważniejsza niż cel. Wartości w życiu i biznesie, Warsaw 2012, p. 335.
} 
become easy and convenient. The strategy used allowed to sell music in iTunes with a low margin and high-end iPods ${ }^{55}$.It is also worth mentioning the film promoting the Apple brand, in which Steve Jobs himself spoke. He stressed that the guiding value is the ability to think differently. This idea has been guiding employees since the founding of the company until today. The great value that Apple praises is care for the environment. In its report on environmental protection, the company provides the following data ${ }^{56}$ :

- at the headquarters in the USA, $80 \%$ is open space with 9,000 drought resistant trees;

- the main office uses $100 \%$ renewable energy;

- $99 \%$ of paper used for packaging production comes from recycling;

- a recycling program has been introduced that can be used for all Apple products used;

- carbon dioxide emissions from Apple's production lines have been steadily declining year by year.

Table 5. Net sales by operating segment and net sales and unit sales by product for 2017, 2016 and 2015 (dollars in millions and units in thousands)

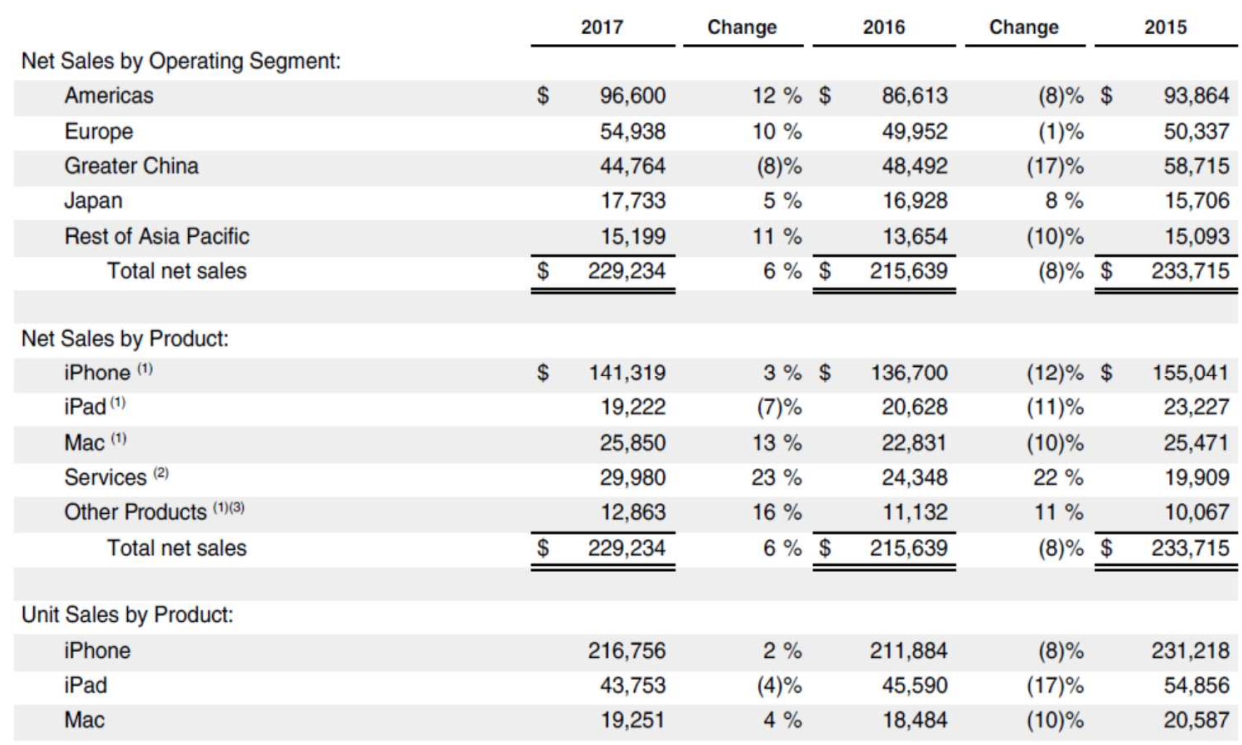

(1) Includes deferrals and amortization of related software upgrade rights and non-software services. (2) Includes revenue from Digital Content and Services, AppleCare, Apple Pay, licensing and other services. Services net sales in the fourth quarter of 2017 included a favourable one-time adjustment of $\$ 640$ million due to a change in estimate based on the availability of additional supporting information.

(3) Includes sales of Apple TV, Apple Watch, Beats products, iPod touch and Apple-branded and third-party accessories.

Source: Annual Report of Apple Inc., 2017, p. 26.

55 A. Stabryła, Strategie rozwoju organizacji, Krakow 2012, p. 200.

${ }^{56}$ Enviromental Responsibility Report. Appple Inc. 2017 Progress Report, Covering Fiscal Year 2016., retrieved from www.apple.com (30.06.2018), p. 4-9. 
Apple also cares about the diversity of employees. It is not important what sex they have, what is their religion or what their skin colour is. Given the tolerance, further development is possible. The company also creates inside organizations that help employees feel an important part of the company, belonging and understood. The following organizations were established: Association of African American Workers; Amigos @ Apple; Association of Jewish Workers; Association of Islamic Workers; Women @ Apple ${ }^{57}$. There is a belief in marketing that satisfied employees are satisfied customers. In the case of Apple, the employees themselves are the attorneys of the organization and build the reputation of the products and brand outside.

Apple is a global brand also in the eyes of customers, recognized around the world, which is why it is characterized by multi-channel shopping and information sources. However, it should be noted that Apple has not been characterized by multi-channelling from the very beginning. According to market experts, in the past, the Management Board did not fully accept brokers in their sales. In addition to its stores, e.g. the iPhone was only available through cellular networks. None of the store chains offering electronic devices could meet all the requirements for Apple. This company sets requirements much stricter for its intermediaries than other large competitors ${ }^{58}$. Apple's multi-channel policy changed only in 2014. Then Komputronik and Sferis were authorized to sell the company's products $^{59}$. Authorization gives the possibility of online stores with electronic devices a chance for big development.

As mentioned earlier, Apple prefers to strictly control its sales, so initially it was run only through its own distribution channels, which is why the iSpot chain of stores was established. Customers can find there a full range of Apple products. Each of the outlets must, however, comply with the strict rules of the Apple Premium Reseller program. Therefore, the employees have specialist certificates. In this way, they have a better chance to meet customer expectations, advice and present products. For example, in Poland, there are 25 iSpot stores ${ }^{60}$. ISpot stores offer a wide range of pre-sale and after-sales services as well as others. Among them, customers can count on:

- trimming the SIM card;

- download photos to a portable storage medium;

- restore the Apple ID password;

- reset the device;

- copy the address book;

- diagnose the device;

- train with selected applications;

- configure the device;

- restore the system;

- start the device for the first time;

- clean the device ${ }^{61}$.

57 Supplier Responsibility, Progress Report 2018, retrieved from www.apple.com (30.06.2018), p. $1-59$.

58 www.crn.pl, (30.06.2018).

${ }^{59}$ Rozszerzenie wspótpracy z Apple KOMPUTRONIK, retrieved from www.komputronik.com (30.06.2018).

60 www.ispot.pl, (30.06.2018).

${ }^{61}$ Ibidem. 
Accordingly, employees must be well trained and certified to provide services at the highest level of the Apple salon. It is also worth paying attention to the fact that iSpot is not only a network of stationary stores, but also online sales. In this way, Apple adapts to the modern requirements of customers.

Apple is also characterized by multichannel sources of information. As it has already been mentioned, there are specialists in company showrooms who will provide reliable information about the brand and its products. However, you should also pay attention to the website, which is especially extensive in English, so that you can find out almost everything about the company.

Building relationships and customer loyalty is a phenomenon that shows how customers identify with the brand. A brand with many loyal consumers has a good chance of getting new ones. Loyalty is also connected with the fact that clients are able to pay for a given brand much more than they would have done in the case of an indifferent company. It is believed that Apple has the most loyal customers in the world. It comes to the situation that when a new product is to enter the market, customers can queue up a few days earlier in front of the store and create a shopping queue list to buy a new release released by Apple ${ }^{62}$.

The most important feature of Apple, through which the company builds relationships and gains customer loyalty, is the confirmation that it is not completely original, but the company repeatedly stressed, for example, that it is not the originator of the mp3 player, but only recreated the idea in a different way than others. In addition, representatives emphasize that the market does not release products that are not better than their predecessors, which is why every time customers can count on a full-fledged, aesthetic and high-quality product. It is also stressed that customer loyalty is associated with a good product. Otherwise, there is no way to gain such favour and trust among customers ${ }^{63}$. As shown below, Apple has twice as many customer loyalties than most competitors. In 2013 the Wall Street Journal commissioned a survey of U.S., U.K. and Australian Smartphone owners to see which manufacturers had the most loyal customers and of course on the top was $76 \%$ of respondents with an Apple iPhone. Samsung was next in the survey with a 58\% retention rate. Third place was LG. 37\% of the respondents with an LG Smartphone, and then Nokia and HTC were close to LG with retention rates of $33 \%$ and $30 \%$ respectively. Sony (24\%), Motorola (22\%) and BlackBerry (21\%) finished the list (Figure 5).

Summing up the considerations regarding building a relationship through Apple, we should mention the research developed by the CIO portal, which collected the six most important features of Apple, which are valued by loyal customers and thus create relationships with the organization. Among them, there are:

- iCloud;

- iOS software;

- X-AXIS;

- style;

- appearance;

- credibility $^{64}$.

\footnotetext{
${ }^{62}$ S. Schneiders, Apple's secret of success - traditional marketing vs. cult marketing, Diplomica Verlag, Hamburg 2011, p. 20.

63 www.betanews (30.06.2018).

${ }^{64}$ www.cio.com (30.06.2018).
} 


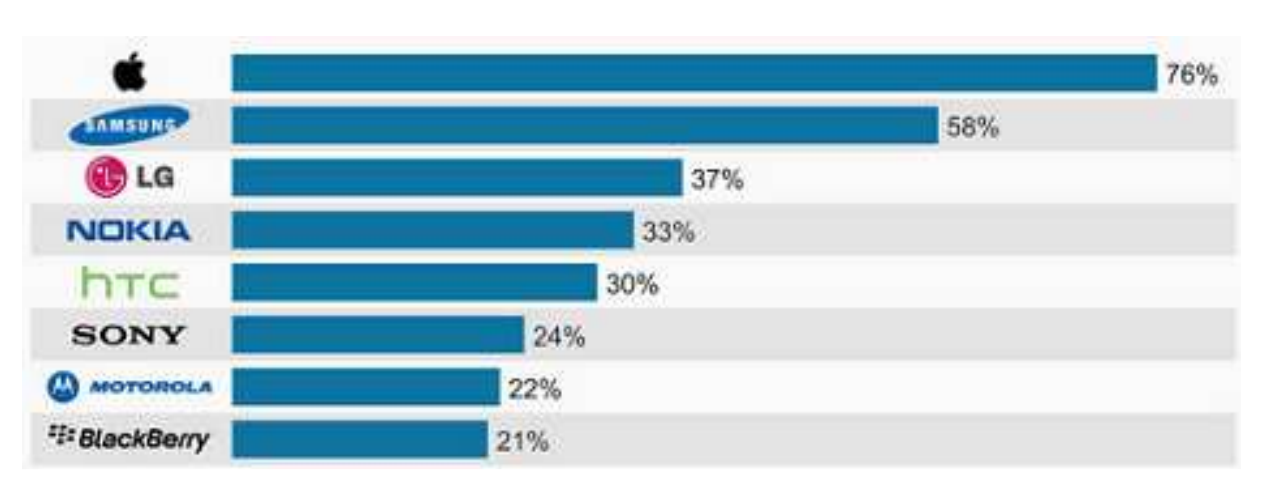

Figure 5. Customer loyalty towards Smartphone brands (2013)

Source: Survey of Smartphone owners shows the power of brand loyalty PHONEARENA, www.phonearena.com, retrieved 30.06.2018.

\section{CONCLUSIONS}

The brand occupies a significant place among the marketing instruments of a modern enterprise. Its position determines the level of enterprise's competitiveness can increase its value and support the processes of winning markets. Undoubtedly, the brand also plays an important role in consumer purchasing decisions, helps to avoid wrong choices, provides consumers with proven quality and increases stakeholders' trust in the company. It is the brand that is the leader among the tools of competing on the market, which proves the company's position and its recognition among various stakeholder groups. Brands draw companies, they rank them mechanically to particular levels of the market, and the condition of the company is directly proportional to the condition of the brands it wields. Taking care of the brand, care is taken for the success of the business as well as for the trust associated with its identification on the market. What's more, its status influences the product, price, shape of the promotion or distribution channels as well as the experiences of the closest stakeholders. This means that as the brand's strength, level of recognition and number of positive associations evokes the company's position in the eyes of its partner's increases as well. Caring about quality, building loyalty among employees (creating employer branding) and external (shaping branding) ensures the possibility of bold application of the policy of high prices and makes the form of promotion on the market dependent on this, as the Apple company is an excellent example.

\section{REFERENCES}

1. Aaker D., Innovation: Brand it or Lose it, "California Review Management" 2007, Vol. 50, No. 1.

2. Aaker D. \& Joachimsthaler E, Brand Leadership, Pocket Books, London 2000.

3. Aaker D. A., Building strong brand, Free Press, New York 1996.

4. Annual Report of Apple Inc. 2017, retrieved from www.apple.com.

5. Bartkowiak P., Sukces przedsiębiorstwa a zarządzanie wartościa klienta [Enterprise success and customer value management], „Zarządzanie i Finanse” R. 11, No. 4/2, 2013. 
6. Bivainiene L., Brand Image Conceptualization: The Role of Marketing Communication, "Economics and Management" 2007, Vol. 12, No. 2.

7. Bhasin, K., Hire people who want to make the best things in the world. Business Insider. (25.08.2011), retrieved from www.bit.ly.

8. Bourne L., Stakeholder relationship management. A maturity model for organisational imple-mentation, Gower, Farnham 2009.

9. Dayyni B., Structured Analytics: The Creation of the Intelligent Organization. "World Academy of Science, Engineering and Technology" 2009, No. 38.

10. Dębski M., Kreowanie silnej marki [Creating a strong brand], Polskie Wydawnictwo Ekonomiczne, Warsaw 2009.

11. Dejnaka A., Budowanie relacji z klientem [Building a customer relationship] [In] Biblia e-biznesu. Ed. M. Dutko, Publishing House Helion, Gliwice 2013.

12. Edwards H., Day D., Kreowanie marek z pasja [Creating brands with passion], Oficyna Ekonomiczna, Krakow 2006.

13. Enviromental Responsibility Report. Appple Inc. 2017 Progress Report, Covering Fiscal Year 2016., retrieved from www.apple.com (30.06.2018).

14. Freeman R.E., Strategic Management: A Stakeholder Approach. Pitman, Boston 1984.

15. Fry S., Steve Jobs, 2011, retrieved from www.stephenfry.com (30.06.2018).

16. Godlewska-Majkowska H., Inteligentna organizacja - dystrybucja wiedzy, kompetencje pracowników, miejsce na rynku [Intelligent organization - knowledge distribution, employee competences, market place], Wydawnictwo Związku Pracodawców Warszawy i Mazowsza, Warsaw 2013.

17. Grudzewski W.M., Hejduk I.K., Przedsiębiorstwo przyszłości [The enterprise of the future], Difin, Warsaw 2011.

18. Isaacson W., Steve Jobs. Simon\&Schuster, New York 2011.

19. Kall J., Jak zbudować silna markę od podstaw [How to build a strong brand from scratch], Helion, Gliwice 2006.

20. Kall J., Silna marka. Istota i kreowanie [A strong brand. Being and creating], PWE Warsaw 2016.

21. Kall J., Hajdas M., Zarzadzanie portfelem marek [Brand portfolio management], Oficyna a Wolters Kluwer business, Warsaw 2010.

22. Kall J., Kłeczek R., Sagan A., Zarzadzanie marka [Brand management], Oficyna Ekonomiczna, Krakow 2006.

23. Kasiewicz S., Rogowski W., Kicińska M., Kapitat intelektualny. Spojrzenie z perspektywy interesariuszy [Intellectual capital. A look from the perspective of stakeholders], Wolters Kluwer, Krakow 2006.

24. Killian S., The importance of brand identity for environmental conservation brands, 2015, document online (20.07.2018).

25. Kotler P., Pfoertsch W., Zarzadzanie marka $w$ segmencie B2B [Brand management in the B2B segment], PWN, Warsaw 2008.

26. Kwarciak B., Wygodna klatka dla klienta [Comfortable cage for the customer], „Modern marketing", no 5/1999, www.modernmarketing.pl (26.02.2018).

27. Kwiatek P., Programy lojalnościowe: budowa i funkcjonowanie [Loyalty programs: construction and functioning], Oficyna a Wolters Kluwer business, Warsaw 2007. 
28. Lahkani K.R., Lifshitz-Assaf H., Tushman M.L., Open innovation and organizational boundaries. The impact of task decomposition and knowledge distribution on the Locus of Innovation, Working paper 12-057/2012, Harvard Business School, May.

29. Lachowski S., Droga ważniejsza niż cel. Wartości w życiu i biznesie [Way more important than the goal. Values in life and business], Studio Emka, Warsaw 2012.

30. Mazurek-Kusiak A.K., Wpływ działań marketingowych małego przedsiębiorstwa na zadowolenie klientów z jakości ustug na przykładzie biura podróży [The impact of marketing activities of a small business on customer satisfaction with the quality of services on the example of a travel agency]. „Pismo Środowiska Badaczy Problemów Rynku: handel wewnętrzny, rynek, przedsiębiorstwo, konsumpcja, marketing” 2013, Vol. 2, No. 3.

31. McQuarrie E.F. \& Phillips B.J., It's not your father's magazine ad: Magnitude and direction of recent changes in advertising style, "Journal of Advertising" 2008, No. 37.

32. Mirońska D., Relacje z interesariuszami organizacji non profit z perspektywy marketingowej [Relations with stakeholders of non-profit organizations from a marketing perspective], Oficyna Wydawnicza Szkoła Główna Handlowa w Warszawie, Warsaw 2016.

33. Mishra P., Apple CIO O`Connor visited Bangalore in January: Will it be iNDIA after iPhone, iPad?. "The Economic Times"2012, retrieved from www.bit.ly (20.07.2018).

34. Osterwalder A., Pigneur Y., Business Model Generation. A Handbook for Visionaries, Game Changers, and Challengers, John Wiley and Sons, Inc., New Yersey 2010.

35. Pinchot G., Pinchot E., The Intelligent Organization, "Executive Excellence" 1990, No. 7(12).

36. Primack D., Fallen Apple: Steve Jobs resigns. retrieved from CNN, August 24/2011.

37. Quinn J.B., The Intelligent Enterprise a New Paradigm, "The Academy Of Management Executive" 1992, No. 6(4).

38. Report "BRANDZ TOP. 100 most valuable global brands in 2018", Kantar Mill Ward Brown. Retrieved from www.brandz.com (30.06.2018).

39. Report "Rewriting the rules for the digital age. 2017 Deloitte Global Human Capital Trends", Deloitte University Press (03.01.2017).

40. Roszkowska-Menkes M., Otwarte innowacje: w poszukiwaniu równowagi [Open innovations: in search for balance], SGH, Warsaw 2015.

41. Rozszerzenie współpracy z Apple KOMPUTRONIK, retrieved from www.komputronik.com (30.06.2018).

42. Schneiders S., Apple's secret of success - traditional marketing vs. cult marketing, DiplomicaVerlag, Hamburg 2011.

43. Schroeder J.E., Visual consumption in the image economy [In:] Elusive consumption, Ed. K. Ekstrom \& H. Brembeck, Oxford, UK: Berg 2004.

44. Skrzypek E., Pinzaru F., Marka jako ważny element marketingu [Brand equity as a key element of marketing], Zeszyty Naukowe Uniwersytetu Przyrodniczo-Humanistycznego w Siedlcach, Seria: Administracja i Zarządzanie, 2017, No. 141.

45. Stabryła A., Strategie rozwoju organizacji [Organization development strategies], Uniwersytet Ekonomiczny w Krakowie, Krakow 2012.

46. Supplier Responsibility, Progress Report 2018, retrieved from www.apple.com (30.06.2018).

47. Survey of smartphone owners shows the power of brand loyalty PHONEARENA 2013, retrieved from www.phonearena.com (30.06.2018). 
48. Sydänmaanlakka P., An Intelligent Organization. Integrating Performance, Competence and Knowledge Management, Capstone Publishing Limited, Oxford 2002.

49. Wereda W., Koncepcja value innovation jako fundament organizacji opartej na innowacyjności i relacjach $z$ interesariuszami [The concept of value innovation as the foundation of an organization based on innovation and relations with stakeholders] [In] Mapa ryzyka $w$ zarzadzaniu organizacja. W kierunku organizacji opartej na innowacjach i kulturze ryzyka. Studia przypadków oraz dobre praktyki, Ed. Wozniak J, Wereda W. CeDeWu, Warsaw 2018.

50. Wereda W., Paliszkiewicz J., Lopes I.T., Woźniak J., Szwarc K., Intelligent Organization (IO) towards contemporary trends in the process of management - selected aspects, Military University of Technology, Warsaw 2016.

51. Wereda W., Woźniak J., Kryterium ryzyka w organizacji "zwinnej” [Risk criterion in the „,agile” organization], „Nowoczesne Systemy Zarządzania” 2015, No. 10.

52. Wozniak J., Wereda W., Mapa ryzyka w zarządzaniu organizacją. W kierunku organizacji opartej na innowacjach i kulturze ryzyka. Studia przypadków oraz dobre praktyki [A risk map in the management of the organization. Towards an organization based on innovation and risk culture. Case studies and good practices], CeDeWu, Warsaw 2018.

53. www.betanews (30.06.2018).

54. www.crn.pl (30.06.2018).

55. www.ispot.pl (30.06.2018).

56. www.applecenter.pl (30.06.2018).

57. www.apple.com (30.06.2018).

58. www.ispot.pl (30.06.2018).

59. www.cio.com (30.06.2018).

\section{KREOWANIE MARKI PRZEDSIEBIORSTWA INTELIGENTNEGO POPRZEZ BUDOWANIE RELACJI Z INTERESARIUSZAMI}

Celem artykułu jest przedstawienie procesu kreowania marki w inteligentnej organizacji, opartego głównie na budowaniu relacji z interesariuszami. We współczesnych organizacjach wiele uwagi poświęca się różnym poziomom inteligencji organizacyjnej, wspieranej przez kreatywność i innowacje różnych grup interesów. Interesariusze wewnętrzni i zewnętrzni coraz częściej bezpośrednio wskazują na to, co ma największy wpływ na ich satysfakcję lub niezadowolenie w ramach współpracy z przedsiębiorstwem. Wiele międzynarodowych badań dowodzi, że silna marka zwiększa liczbę korzyści dla organizacji, takich jak: wzbudzanie zaufania wśród zainteresowanych stron z punktu widzenia produktów/usług czy kultury organizacyjnej przedsiębiorstwa, szansa na budowanie lojalności klientów, psychologiczna ocena wizerunku organizacji, umożliwienie pozycjonowania firmy na rynku percepcji oraz w cyberprzestrzeni, stabilizowanie pozycji rynkowej przedsiębiorstwa i inne. Zainteresowane strony w większości przypadków oczekują więcej inicjatyw od przedsiębiorstwa w ramach procesu wspólnego zaangażowania, a organizacja może osiągnąć przez to wiele celów, zaspokajając potrzeby partnerów i tworząc silną markę na rynku. Zatem można założyć, iż budowanie stałych relacji z interesariuszami oraz wzmacnianie ich zaangażowania we współczesnym świecie biznesu ma permanentne znaczenie w kreowaniu marki oraz wizerunku każdej organizacji. Autorka stara się zdefiniować cechy marki inteligentnej organizacji i wymienić różne aspekty 
„,inteligencji” w przedsiębiorstwie, na podstawie literatury przedmiotu i własnych badań, czyli na przykładzie studium przypadku - prezentując działania firmy Apple.

Słowa kluczowe: kreowanie marki, przedsiębiorstwo inteligentne, relacje z interesariuszami, firma Apple

DOI: $10.7862 / /$ rz.2018.mmr.58

Tekst złożono do redakcji: wrzesień $2018 \mathrm{r}$.

Tekst przyjęto do druku: grudzień 2018 r. 
